\title{
Influence of Employees' Perceived Organizational Support and Job Performance on Customer Satisfaction: An Empirical Support from Nepalese Hospitality Sector
}

\author{
Gangaram Biswakarma \\ Tribhuvan University, Kathmandu \\ drgrbiswa@gmail.com
}

\begin{abstract}
This study investigated the interrelationship of Perceived Job Performance (PJP), Perceived Organizational Support (POS) and International Customer Satisfaction (CS) in Nepalese hospitality sector. The data were collected with 152 international customers and 158 hotel employees. Results indicate that Perceived Job Performance and Perceived Organizational Support is directly related to International Customer Satisfaction, though no direct effect of Perceived Organizational Support over Customer Satisfaction was found. Perceived Organizational Support significantly mediates partially between Perceived Job Performance and Customer Satisfaction. Thus, Perceived Job Performance can strongly relate with achieving higher level of Customer Satisfaction in hospitality sector with mediations of Perceived Organizational Support. It signifies that hospitality industry in Nepal, should pledge a proper inventiveness in the direction of creating an organizational employee supportive environment that need to increase the effect of job performance towards achieving the ultimate goal of customer satisfaction.
\end{abstract}

Keywords: Perceived Organizational Support (POS), Perceived Job Performance (PJP),

Customer Satisfaction (CS), Nepal, Hospitality industry in Nepal

\section{Introduction}

In today's competitive market environment, a top priority for hospitality firms is to deliver service quality (Karatepe, 2011). The quality of service critically resulted in customer satisfaction. One of the components of quality of service and its sustainability depends on employees' performance. Frontline employees play the most critical role in this process (Bouranta et al., 2009; Yavas et al., 2010). Efforts to enhance customer satisfaction have been considered critical by many organizations, particularly those in the service sector (Schmit and Allscheid, 1995). It is critical when 
the hospitality industry caters the overall tourism industry, where international tourist plays an important role in the expansion of tourism sector. In service organizations, employees interact directly with their customers (service users) in service encounters. The interaction between the employees and customers are more important in service organization. Customer satisfaction is one of the most investigated topics in the tourism and hospitality industry due to its role in the survival and future of any tourism products and services (Gursoy, McCleary, \& Lepsito, 2007). In services setting, customer satisfaction mainly depends on the process of service delivery a fact that highlights the important role of the front-line employees' performance.

The critical role in the employees' performance, they are to be sufficiently supported by the organisation. So that, the employee create a desired to work and feel that their contributions are valued by the organization and that the organization cares about their well-being (Eisenberger et al., 1986). Significantly, influences both individual and organizational performances, ranging from the employee's physical/psychological well-being and job satisfaction to customer service quality/ performance and customer satisfaction (Hur, et al. 2105). Accordingly, this study focuses in order to add value to the deeper understanding of influence of employees' perceived job performance, employees' perceived organizational support on customer satisfaction in Nepalese hospitality industry. Secondly, this study also examines a conceptual model of mediating influence of perceived organizational support over the effect of job performance on customer satisfaction.

\section{Research Objective/s}

This research aims to investigate the relationship between Employees' Perceived Job Performance (PJP), Employees' Perceived Organizational Support (POS), and International Customer Satisfaction (CS) in Nepalese hospitality industry.

\section{Literature Review}

A significant stream of research in organizational studies focuses on both the internal functioning of the service organization and the effect of this functioning on customer satisfaction (e.g. Wiley, 1996; Ryan et al., 1996, Hartline and Ferrell, 1996). Many 
firms use customer satisfaction measurements to evaluate the performance of goods, services and employees and try to link them to customer attitudes and behavior (Peterson \& Wilson, 1992; Johnson \& Gustafsson, 2000; Olsen, Witell, \& Gustafsson, 2014). Several studies have focused on customer satisfaction in different perspectives. These literatures state that the customer satisfaction can depend on a series of elements that belong to the subjective sphere of the customer and to the objective quality of the product/service experienced (Biswakarma, 2015). As the perceived quality of service is often determined by the manner in which service employees not only act and speak with the customer but also how they regulate their feelings, most service organizations encourage their employees to manage their emotions in service interactions to maximize customer satisfaction (Bryman, 2004). However, researchers have questioned this simple method of directly linking positive emotional display or the regulation behavior of service employees with customer satisfaction (Söderlund and Rosengren, 2008, 2010). For example, the higher POS employees have, the higher their job satisfaction and job performance, in particular, will be due to an intense sense of obligation to repay their organizations (Eisenberger et al., 2001). Researches indicate that companies with an excellent customer service record reported a $72 \%$ increase in profit per employee, compared to similar organizations that have demonstrated poor customer service; it is also five times costlier to attract new customers than to retain existing customers (Duncan, 2004; Duncan \& Elliott, 2004). Bitner (1992) also supported the notion that employee and customer responses to the firm environment influence the social interaction between them. In similar manner, $\mathrm{j}$ ob performancehas been shown to be the best method for achieving better hotel service, productivity, and efficiency as well as improving guest satisfaction (Sternberg, 1992).

\subsection{Employees' Perceived Job Performance and Customer Satisfaction}

Much of the burden for customer perceptions of service quality lies on front-line personnel (Hoffman and Ingram, 1992). The consequences of customer satisfaction is linked with employee performance in several studies. Previous empirical studies evidently presents strong relationship between employee performance and customer 
satisfaction. Study of Douglas, Thomas, \& Ingram, (1992) and Frederick Reichheld (2000), presents a positive correlation with customer oriented behavior and concluded that employee performance is essential to customer satisfaction. Likewise, Heskett, Jones, Loveman, Sasser, and Schlesinger (1994) establish a framework in which internal service quality drives employee satisfaction, which, in turn, drives employee performance that generates service quality. Employee with their job performance interact with customers and affect the perception of the customer.

\subsection{Employees' Perceived Organizational Support and Customer Satisfaction}

There are few previous studies based on the direct relationship of Organizational support and customer satisfaction. Perceptions from both the frontline employees and their customers, reveals that some job resources as elements of organizational support exert its impact on several employee behaviors as well as direct impact on customer satisfaction (Siddiqi, 2014). Studies like Singh \& Singh (2010), Hassan, Hassan, \& Shoaib (2014) argues in the direction of relationship between POS and CS. POS significantly moderated the relationship between surface acting and job satisfaction, as well as the relationship between deep acting and job performance (Hur, 2014). Hur (2014) study indicated that POS increases or decreases the relationship between emotional labor and job-related outcomes. Employees' work efforts are manifested through their sense-making of the endorsement provided by their organization, which enhances their job performance (Duke et al., 2009).

\subsection{Perceived Organizational Support and Perceived Job Performance}

POS refers to "the extent to which the organization values [employees'] contributions and cares about their well-being" (Eisenberger, Huntington, \& Hutchison, 1986). POS has been previously investigated as the willingness of an organization to provide employees with adequate working conditions and assignments (Eisenberger et al., 1986). The idea of POS was first introduced officially by Eizenberg in an article in organizational literature 1986 (Hakkak, Gashti, \& Nawaser, 2014). POS captures an employee's beliefs concerning the extent to which the organization values 
(employees') general contributions made on the organization's behalf and cares for their well-being (Eisenberger, Huntington, \& Hutchison, 1986; Wickramasinghe \& Wickramasinghe, 2012).

POS can have direct and indirect effect on employee behavior and the relation between them (Hakkak, Gashti, \& Nawaser, 2014). Armeli, Eisenberger, Fasolo, \& Lynch, (1998), studied patrol officers in USA with high socio-emotional needs, found that there was generally a positive relationship between POS and performance. POS is the extent to which employees perceive that the organization values their contributions and cares about their well-being (Guan, Sun, Hou, Zhao, \& Luan, 2014). POS may be encouraged by employees' tendency to ascribe human-like traits or characteristics to organizations (Eisenberger, Huntington, \& Hutchison, 1986).

Positive relationship between POS and work-related outcomes has been found in the study like Armeli, Eisenberger, Fasolo, \& Lynch (1998), Rhoades and Eisenberger (2002), Susskind et al. (2000). Karatepe (2012) study suggested that perceived organizational support influenced service recovery performance and job performance. Likewise, POS was found positively related to evaluative and objective measures of performance in standard job activities (Armeli, Eisenberger, Fasolo, \& Lynch, 1998, Eisenberger, Huntington, \& Hutchison, 1986). In other studies like Settoon, Bennett, \& Liden, (1996) and Wayne, Shore, \& Liden (1997), it was found no relationship between POS and work performance using structural equation modeling. In conclusion, previous studies emphasized that job performance leads to customer satisfaction via perceived organizational support.

\section{Research Gaps}

Most of the research in international arena has covered or focused PJS and PJP as determinants of CS. However, to the best of author's knowledge, few studies focused on employee POS and CS in the past. Specially, in Nepalese context there is no study to empirically support the relationship of POS as a determinant of CS. At the same time, research in the area that explores relationship between PJP, POS and CS in a single model has not been undertaken. Therefore, having identified this gap in the 
extant literature, the present study that along with these linkages, investigates the impact of PJP, POS on CS. It is a valuable attempt to plug the gap.

\section{Research Framework and Hypotheses}

Based on literature review the relationship of PJP, POS, and CS seen under the proposed framework in Figure 1. Based on literature arguments, the hypotheses were advanced to identify the relationship of PJP, POS, and CS.

H1: PJP has significant positive direct effect on CS

H2: POS has significant positive direct effect on CS

H3: POS will mediate the influence of PJP on CS

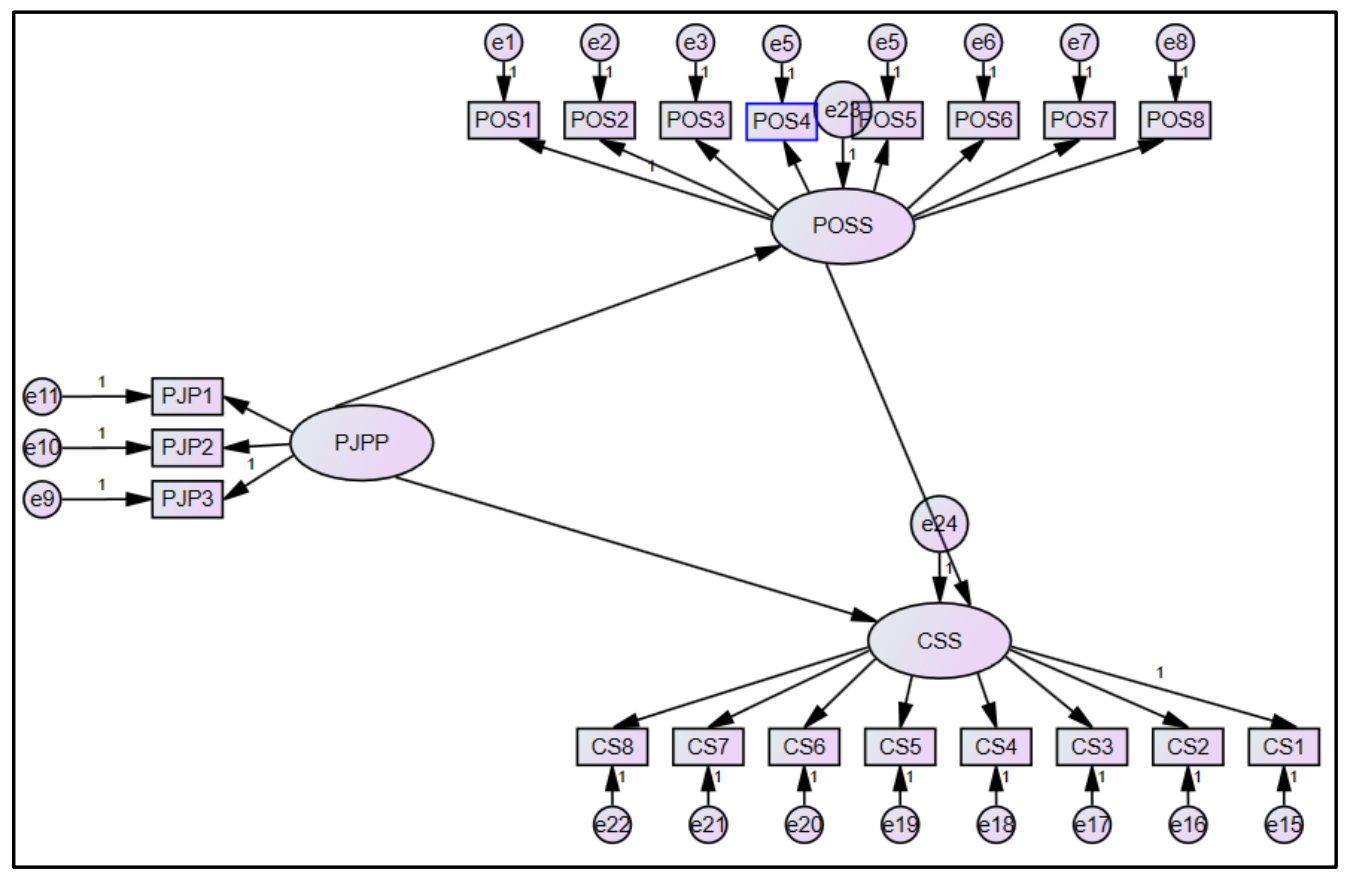

\section{Figure 01: Model of Hypothetical Relationships}

\section{Research Design, Sampling and Data Collection}

This study undertakes quantitative approach towards descriptive and causal research design. A descriptive research design was used for answering the current situation of PJP, POS and CS in Nepalese hospitality sector. Similarly, the need of explanatory research design needed and reflects to test the relationship and impact of independent 
variables over the dependent variable in this study. This study nested a research design in which allows incorporating both levels employees and customers in a single investigation. SEM analysis was adopted to examine the hypotheses. A sample of 200 customers and 200 employees were considered for the study. For the reliability of perception of the employee towards their respective organizations, employee having at least six months of working experience considered as valid sample. The customer and employees samples comprises of star category hotels in Kathmandu Valley. The data was collected from these hotels with convenience sampling method, in which 200 questionnaires for customers and 200 questionnaires for Employees were distributed out of which 152 nos. for customers and 158 nos. of employees were in the position of utilization. The response rate was $76 \%$ for customer's responses and $79 \%$ for employee's responses. The detail list of sample collection can be seen at table 01 .

\section{Table 01: Hotels taken for the Study}

\begin{tabular}{lrrlrr}
\hline \multicolumn{1}{c}{ Customers } & & & \multicolumn{2}{c}{ Employees } \\
\hline Hotel & $\mathbf{N}$ & $\mathbf{\%}$ & Hotel & $\mathbf{N}$ & $\mathbf{\%}$ \\
\hline Airport Hotel & 8 & 5.3 & Airport Hotel & 8 & 5.06 \\
Ambassadors & 2 & 1.3 & Ambassadors & 9 & 5.70 \\
Everest Hotel & 8 & 5.3 & Everest Hotel & 10 & 6.33 \\
Hotel Annapurna & 6 & 3.9 & Hotel Annapurna & 11 & 6.96 \\
Hotel Malla & 6 & 3.9 & Hotel Manang & 7 & 4.43 \\
& & & Thamel & & \\
Hotel Manang & 2 & 1.3 & Hotel Shanker & 8 & 5.06 \\
Thamel & & & & & \\
Hotel Shanker & 6 & 3.9 & Hotel Vaishali & 9 & 5.70 \\
Hotel Vaishali & 12 & 7.9 & Hyatt Regency & 14 & 8.86 \\
Hyatt regency & 26 & 17.1 & Hotel Malla & 15 & 9.49 \\
Marcopolo & 4 & 2.6 & Marcopolo & 12 & 7.59 \\
Business & & & Business & & \\
Radission & 16 & 10.5 & Radission & 11 & 6.96 \\
Shangri-la Hotel & 40 & 26.3 & Shangri-la Hotel & 17 & 10.76 \\
Soaltee & 8 & 5.3 & Soaltee & 13 & 8.23 \\
Yak and Yeti & 8 & 5.3 & Yak and Yeti & 14 & 8.86 \\
N & $\mathbf{1 5 2}$ & $\mathbf{1 0 0}$ & N & $\mathbf{1 5 8}$ & $\mathbf{1 0 0}$ \\
\hline
\end{tabular}




\section{Conceptual Model and Instrumentation}

The conceptual framework for this study constitute of three construct- Perceived Organization Support (POS), Perceived Job Performance (PJP) and Customer Satisfaction (CS). Rhoades et al., (2001) Perceived organizational support (POS) scale with eight items, Bowra et al., (2011) Perceived Job Satisfaction (PJS) scale with three items and Gunarathne (2014) Customer Satisfaction (CS) 7 items scale in 5 point likert scale was adopted for the study.

\section{Analytical Strategy}

At first, the variables were put into the Exploratory Factor Analysis (EFA) to ensure the factor loading of the items into its latent variables. Next, a two-stage approach of CFA and SEM was performed to test the hypothesis to identify significant direct and indirect effect of variables. Based on data obtained from hotel employees and customers, the hypothesized relationships were tested using AMOS v23 through structural equation modeling and other descriptive analysis was performed with SPSS v23.

\section{Results}

\subsection{Demographic Profile of Respondents}

The majority of respondents $68.4 \%(n=104)$ were male, female constituted of $31.6 \%$ $(n=48)$. The customers sample constituted of largest $44.7 \%$. $(n=68)$ of age group of 21 to 30 years. Maximum of the customers were married with $57.2 \%(n=87)$. Similarly, customer respondents' top three country of origins were Indian $23.7 \%$ $(n=36)$, American 10.5\% $(n=16)$ and French $10.5 \%(n=16)$, the least were Tibetan $1.3 \%(n=2)$. Similarly, the majority of employee respondents were male $58.9 \%$. $(n=93)$, female employees constituted of $41.1 \%(n=65)$. The employees' sample constituted of $58.2 \%(n=92)$ in age group of 21 to 30 years. Maximum of the employees were single with $58.9 \%(n=93)$. Table 2 presents detail results. 
Table 02: Profile of the Respondents

\begin{tabular}{|c|c|c|c|c|c|c|c|c|c|c|c|}
\hline \multicolumn{3}{|c|}{ Customers } & \multicolumn{3}{|c|}{ Employees } & \multicolumn{3}{|c|}{ Customers } & \multicolumn{3}{|c|}{ Employees } \\
\hline Gender & $N$ & $\%$ & Gender & $n$ & $\%$ & $\begin{array}{c}\text { Country of } \\
\text { origin }\end{array}$ & $n$ & $\%$ & Income & $n$ & $\%$ \\
\hline Female & 48 & 31.6 & Female & 65 & 41.1 & American & 16 & 10.5 & Below 20000 & 26 & 17.1 \\
\hline Male & 104 & 68.4 & Male & 93 & 58.9 & Australian & 8 & 5.3 & $20000-30000$ & 68 & 44.7 \\
\hline Total & 152 & 100 & Total & 158 & 100 & Canadian & 12 & 7.9 & $30000-40000$ & 39 & 25.7 \\
\hline Marital Status & $n$ & $\%$ & Marital Status & $n$ & $\%$ & Chinese & 12 & 7.9 & $\begin{array}{l}40000 \text { and } \\
\text { above }\end{array}$ & 19 & 12.5 \\
\hline Single & 56 & 36.8 & Single & 93 & 58.9 & Cambodian & 4 & 2.6 & Total & 152 & 100 \\
\hline Married & 87 & 57.2 & Married & 62 & 39.2 & French & 16 & 10.5 & & & \\
\hline $\begin{array}{l}\text { Divorced/ } \\
\text { widowed }\end{array}$ & 9 & 5.9 & $\begin{array}{l}\text { Divorced/ } \\
\text { widowed }\end{array}$ & 3 & 1.9 & German & 10 & 6.6 & & & \\
\hline Total & 152 & 100 & Total & 158 & 100 & Indian & 36 & 23.7 & & & \\
\hline $\begin{array}{l}\text { Age group in } \\
\text { yrs. }\end{array}$ & $n$ & $\%$ & $\begin{array}{l}\text { Age group in } \\
\text { yrs. }\end{array}$ & $n$ & $\%$ & Italian & 8 & 5.3 & & & \\
\hline Below 20 & 2 & 1.3 & Below 20 & 23 & 14.6 & Japanese & 12 & 7.9 & & & \\
\hline $21-30$ & 68 & 44.7 & $21-30$ & 92 & 58.2 & Kiwis & 8 & 5.3 & & & \\
\hline $31-40$ & 50 & 32.9 & $31-40$ & 38 & 24.1 & Portuguese & 4 & 2.6 & & & \\
\hline 40 and above & 32 & 21.1 & 40 and above & 5 & 3.2 & Tibetan & 2 & 1.3 & Customers: $\mathrm{N}$ & Emplo & $\mathrm{N}=158$ \\
\hline
\end{tabular}




\subsection{Exploratory Factor Analysis (EFA)}

Before analyzing the model with CFA and SEM, the factor loading of latent variables was confirmed by EFA with Principal Component Analysis, component rotated with Varimax with Kaiser Normalization. EFA shows respective latent variables and items were confirmed in the same factors in measurement. KMO and the Bartlett's test of sphericity is presented in Table 3. KMO was 0.899, which was above the lower threshold of 0.5 . Likewise, the Bartlett's test of sphericity suggests statistical significance of the correlations among the observed variables. The Chi-square value $(2861.408,171)$ is statistically significant at $(\mathrm{p}=0.001)$, place in table 3 . The factors are extracted with 1 or higher eigenvalues, as suggested by Guttman, considers factors with an eigenvalue greater than one as common factors (Nunnally, 1978). In the event of that, total variance as explained by the three factors was $74.436 \%$ cumulative variance. The factor loading of the three factors is placed in Annexure-1.

\section{Table 03: KMO and Bartlett's Test}

\begin{tabular}{llr}
\hline Kaiser-Meyer-Olkin & & .899 \\
Bartlett's Test of & Approx. Chi-Square & 2861.408 \\
Sphericity & df & 171 \\
& Sig. & .001 \\
\hline
\end{tabular}

\subsection{Confirmatory Factor Analysis (CFA)}

Erstwhile to examining the relations among the variables, the subscale or the construct of latent variables was analyzed with confirmatory factor analysis to establish its unidimensionality of the whole construct (questionnaire items). Forthwith, a certain degree of model fit is necessary before the testing of the general model is done (Mulaik \& James, 1995). So, CFA model fit test was done. Table 4 presents the results of the CFA and figure 2 present the structural model with factor loading. There should be at least 3 items with significant loadings (>0.30) (Suhr, undated). In view of this, all factor loading are higher than 0.5. Correspondingly, on the basis of the modifications indices, the model fit has been achieved. Modification indices suggested remedies to discrepancies between the proposed and estimated model. 
Standard residual covariance was tested for significantly decreasing the model fit. Fixing the model fit, few items in latent variables were covariate. POS8, POS5, and POS3 in POS latent variable; CS1, CS2, CS3, CS4, CS6, and CS8 in CS latent variable were covariate. Similarly, POS4 has been deleted to achieve Model fit indices.

\section{Table 04: Summary of Model Fit Indices for Structural Model of Service Quality}

\begin{tabular}{lc}
\hline \multicolumn{1}{c}{ Measures } & Observed Values of the Model \\
\hline$\chi 2$ & 241.366 \\
$\mathrm{p}$ & 0.001 \\
$\mathrm{df}$ & 126 \\
$\mathrm{CMIN} / \mathrm{df}$ & 1.916 \\
$\mathrm{RMSEA}$ & 0.068 \\
$\mathrm{PCLOSE}$ & 0.06 \\
$\mathrm{GFI}$ & .861 \\
$\mathrm{CFI}$ & .958 \\
$\mathrm{AGFI}$ & .811 \\
$\mathrm{PCFI}$ & 0.789 \\
$\mathrm{IFI}$ & .958 \\
TLI & .949 \\
PGFI & .634 \\
\hline$\chi 2=$ Chi-Square; $p$ - value for the model, Df= Degree of freedom; $R M S E A=$ Root mean \\
square error of approximation fit index; PCLOSE=p of Close Fit, GFI= goodness of fit \\
index; CFI= Comparative fit index; AGFI= Absolute goodness of fit index; PCFI= \\
Parsimony goodness of fit index; IFI= Incremental fit index; TLI= Tucker Lewis index; \\
PGFI= Parsimony goodness of fit index.
\end{tabular}

Results from the estimation from the model yielded overall fit indices for the CFA model, which were acceptable threshold, with $\chi 2 / \mathrm{df}=241.366, \mathrm{CMIN} / \mathrm{Df}=1.916$, $\mathrm{p}=0.001$. The measurement model has a good fit with the data based on assessment criteria such as GFI, CFI, TLI, RMSEA (Nejatian, et, all., 2011; Bagozzi \& Yi, 1988). RMSEA $=0.068(<0.08$, Browne \& Cudeck, 1993; <0.05, Stieger, 1990; < $0.05 \mathrm{Hu}$ and Bentler, 1999). CFI=0.958 indicating model Good Fit, within the upper threshold of >.95 ( Hu and Bentler (1999). PCLOSE= 0.06 (>.05 Hu and Bentler, 1999). AGFI=.811 (>.80 Hu and Bentler, 1999). PCFI=0.789 (> 0.50 James, Mulaik \& Brett 1982). $\mathrm{IFI}=0.958, \mathrm{TLI}=0.949$, within the threshold $(>0.90$ Tucker \& Lewis 1973), PGFI $=0.634$ (>0.50 James, Mulaik \& Brett 1982). GFI was 0.861. At least three 
indices must be fitted well to determine the model fit (Hair et al., 2010). Table 4 and figure 02 presents the summary of model fit indices.

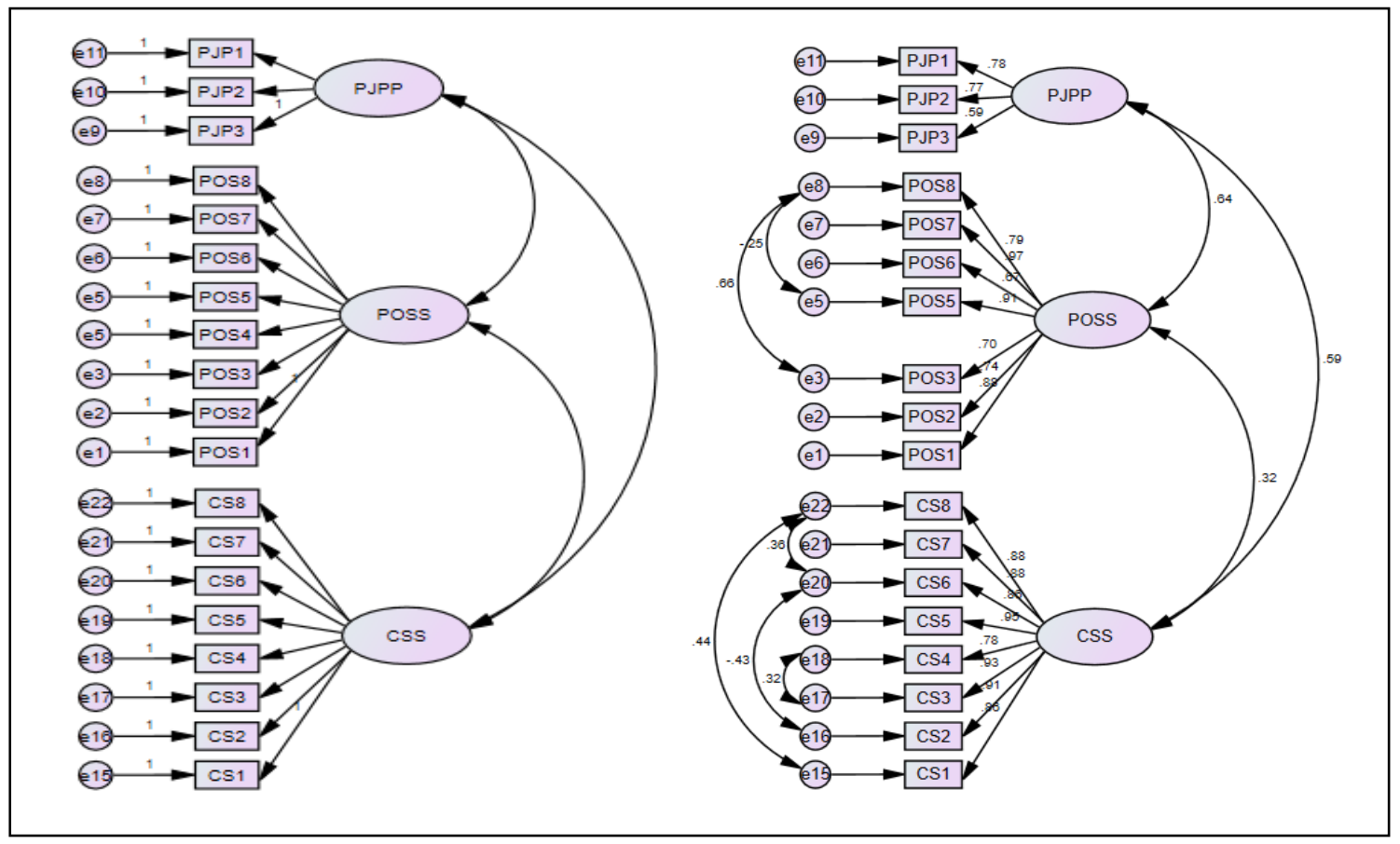

Figure 02: CFA of Latent Variable Construct (Proposed and Final Model Construction)

\subsection{Reliability, Convergent Validity and Discriminant Validity}

Table 05 presents the result of the reliability and validity. FL, CR and AVE were used to test convergent validity. MSV and ASV were used to test the discriminant validity of the measurement model. Similarly, reliability was analyzed with CA. Reliability with the indices of $\mathrm{CR}>0.7$, Convergent Validity with the indices of $\mathrm{CR}>\mathrm{AVE}$, AVE >.5, Discriminant Validity with the indices of MSV < AVE, ASV < AVE (Hair et al., 2010). This is a satisfactory level of internal consistency of the measures and there exist some common points of convergence (Hair et al., 2010). This indicates measurement model is according to the assumptions which were originally made. 
Table 05: Reliability and Validity

\begin{tabular}{|c|c|c|c|c|c|c|c|}
\hline Constructs & Items & $\begin{array}{l}\text { Factor } \\
\text { Loadings }\end{array}$ & $\begin{array}{c}\text { Cronbach's } \\
\text { Alpha }\end{array}$ & CR & AVE & MSV & ASV \\
\hline \multirow[t]{7}{*}{ POS } & POS1 & .89 & .929 & .823 & 0.67 & 0.1 & 0.62 \\
\hline & POS2 & .74 & & & & & \\
\hline & POS3 & .70 & & & & & \\
\hline & POS5 & .91 & & & & & \\
\hline & POS6 & .67 & & & & & \\
\hline & POS7 & .97 & & & & & \\
\hline & POS 8 & .79 & & & & & \\
\hline \multirow[t]{3}{*}{ PJP } & PJP1 & .78 & .752 & .759 & 0.52 & 0.4 & 0.4 \\
\hline & PJP2 & .77 & & & & & \\
\hline & PJP3 & .59 & & & & & \\
\hline \multirow[t]{8}{*}{$\mathrm{CS}$} & CS1 & .86 & .966 & .966 & 0.78 & 0.1 & 0.46 \\
\hline & CS2 & .91 & & & & & \\
\hline & $C S 3$ & .93 & & & & & \\
\hline & CS4 & .78 & & & & & \\
\hline & CS5 & .95 & & & & & \\
\hline & CS6 & .86 & & & & & \\
\hline & CS7 & .88 & & & & & \\
\hline & CS8 & .88 & & & & & \\
\hline
\end{tabular}

Composite Reliability (CR), Average Variance Extracted (AVE), Maximum Shared Squared Variance (MSV), and Average Shared Squared Variance (ASV).

POS: Perceived Organization Support; PJP: Perceived Job Perception; JS: Job

Satisfaction; CS: Customer Satisfaction

\section{Perceived Job Performance, Perceived Organizational Support and Customers' Satisfaction in Nepalese Hospitality Sector}

The result indicated that there is a moderate level of PJP and POS in hospitality sector in Nepal with a mean value of 3.72 ( $\mathrm{SD}=0.636)$, and $3.59(\mathrm{SD}=0.56)$. Correspondingly imperative, the level of satisfaction has a mean value of 3.61 $(\mathrm{SD}=0.78)$, that indicates a moderate level satisfaction.

Table 06: Descriptive Statistics of POS, PJP and CS

\begin{tabular}{ccc}
\hline Variables & Mean & SD \\
\hline PJP & 3.72 & 0.636 \\
POS & 3.59 & 0.56 \\
CS & 3.61 & 0.78 \\
\hline
\end{tabular}




\subsection{SEM Path Analysis}

Structural path analysis was performed to investigate the research hypotheses by using AMOS v23. The results indicates that, the research model has near good fit to indices as recommended by SEM literature (Hair et al., 1998; Bollen, 1989): with $\chi 2 / \mathrm{df}=$ 417.136/132, CMIN/Df=2.16, p=0.001. RMSEA = 0.72, PCLOSE=0.043.

\subsection{Correlation Analysis}

Correlation matrix is presented in table 7, it indicates that there is a comparatively moderate to strong correlation between PJP and POS with $\mathrm{r}=0.568, \mathrm{p}=0.001, \mathrm{PJP}$ and CS with $\mathrm{r}=0.507, \mathrm{p}=0.001$. Similarly, comparatively moderate correlation between POS and CS with $\mathrm{r}=0.346, \mathrm{p}=0.001$. As expected, a positive moderate to strong relationship between the variables was achieved.

Table 07: Correlations matrix of POS, PJP and CS

\begin{tabular}{lccrr}
\hline Variables & & PJP & \multicolumn{1}{c}{ POS } & \multicolumn{1}{l}{$\boldsymbol{C S}$} \\
\hline $\boldsymbol{P J P}$ & $r$ & 1 & $.568^{* *}$ & $.507^{* *}$ \\
$\boldsymbol{P O S}$ & $r$ & $.568^{* *}$ & 1 & $.346^{* *}$ \\
$\boldsymbol{C S}$ & $r$ & $.507^{* *}$ & $.346^{* *}$ & 1 \\
\hline
\end{tabular}

**. Correlation is significant at the 0.01 level (2-tailed).

\subsection{Impact Analysis}

The model path analysis shows the Regression Weights heading the standardized loadings along with standard errors and p-values that are presented in table 8. PJP -> CS unconstrained estimates are significant, whereas insignificant in POS -> CS. The Standardized Regression Weights can be interpreted as the correlation and influence between the observed variable and the corresponding common factor. PJP-> CS is significant at the 0.01 level. The construct of POS ->CS has no significant influence on each other with $\mathrm{p}>0.05$ level. The Standardized Regression Weights is comparatively high in factor construct of PJP->CS than POS -> CS constructs. 


\section{Hypothesis Testing (SEM)}

In view of the above, the regression weight had made it clear understanding of impact of PJP on CS but not explained in POS and CS directly. The results shows PJP positively affects the CS $(\beta=0.654, \mathrm{p}<0.01)$, would cause the CS to increase by $65.4 \%$. Hence, path analysis determined the theoretically based hypotheses PJP has significant positive direct effect over the CS. However, POS does not have direct effect over CS.

The hypotheses were verified using the values (shown in the path diagram in figure 3 and table 8) $\mathrm{H} 1$ is accepted, however, $\mathrm{H} 2$ is failed to be accept.

Table 08: Standardized Regression Weights (SME Model)

\begin{tabular}{lllrrr}
\hline Hypothesis & Exogenous & Endogenous & $\begin{array}{c}\text { Estimate } \\
\text { (Standardized) }\end{array}$ & S.E. & \multicolumn{1}{c}{ P } \\
\hline H1 & PJP & - CS & 0.654 & 0.234 & $* * *$ \\
H2 & POS & - CS & 0.093 & 0.126 & 0.397 \\
& & & & & $\mathrm{R}^{2}=0.56$ \\
\hline
\end{tabular}

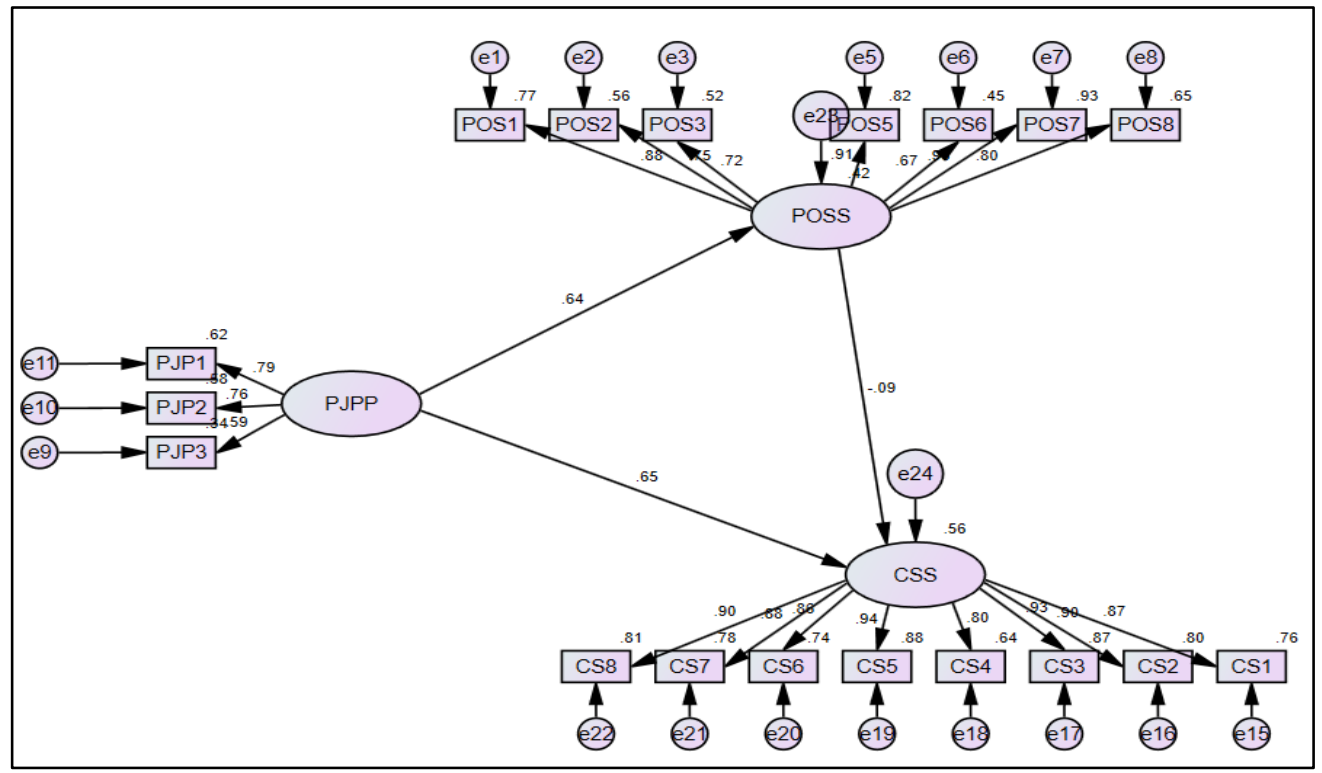

Figure 03: SEM- Path Analysis 


\section{Mediating role of Perceived Organizational Support towards Perceived Job Performance over Customer Satisfaction}

The current model also investigated the mediating role of POS towards PJP over CS with formulation of $\mathrm{H} 3$. The direct effect by the construct model was performed first and later the mediation effects were analyzed based on the respective hypothesis. The construct for mediation test was performed through SEM (path analysis) with bootstrapping. The bootstrap estimates presented were based on 2000 sample and Bias-corrected CI at $95 \%$. H3 was verified using the values of direct beta without mediation, direct beta with mediation and indirect beta as shown in table 9 . The result indicates that POS have partial mediation towards PJP on CS. It signifies that there is a mediating effect of POS over the relationship of PJP and CS. It signifies not only the importance of the employees' perception on organizational support towards their job performance, it too indicates the importance of organizational support towards customer satisfaction. Hence, H3 is accepted, as there is a mediation relationship in between the variables under observation PJP->POS->CS.

\section{Table 9: Summary of Hypothesis Testing to Identify Mediation}

\begin{tabular}{lllllc}
\hline $\begin{array}{c}\text { Hypothesis } \\
\text { No. }\end{array}$ & Hypothesis & $\begin{array}{c}\text { Direct Beta } \\
\text { w/o Med }\end{array}$ & $\begin{array}{c}\text { Direct Beta } \\
\text { w/Med }\end{array}$ & $\begin{array}{c}\text { Indirect } \\
\text { Beta }\end{array}$ & $\begin{array}{c}\text { Mediation } \\
\text { type } \\
\text { observed }\end{array}$ \\
\hline H3 & PJP-POS-CS & $.654^{* * *}$ & $.115^{* *}$ & $.030^{* *}$ & Partial \\
\hline
\end{tabular}

Note: bootstrap sample $=2000 ; * * * \mathrm{p}<.01, * * \mathrm{p}<0.05$ and $\mathrm{ns}=$ not significant.

\section{Discussion and Conclusion}

As a result of empirical findings that demonstrate, the significant relationship between PJP, POS and CS. Additionally the partial mediation of perceived organization support in hospitality industry in Nepal. This research paper contributed in understating of relationship between PJP, POS and CS. Diverse samples of employees and customers from the hospitality industry in Kathmandu, Nepal are used for the study. The finding indicates that PJP has a strong direct relationship with CS, it supports the study of Douglas, Thomas, \& Ingram, (1992) and Frederick Reichheld (2000) and Heskett, Jones, Loveman, Sasser, and Schlesinger (1994). 
It is also empirically proved that the consequences of customer satisfaction is also linked with POS with weak to moderate relationship with CS, it supports previous studies of Siddiqi, (2014), Hur (2014), Singh \& Singh (2010), Hassan, Hassan, \& Shoaib (2014). However, it is found that there is no direct impact of POS on CS. The lack of a noteworthy direct effect from POS on CS does not diminish the value of the former.

Similarly, it has been established that employee perceived organizational support exerts a partial mediation influence on customer satisfaction. As such, employee PJP is manifested as one important antecedent of the customer's satisfaction, albeit indirectly through the development of organizational support between employee and customers. The result supports studies like Spiro and Weitz (1990), Jeon \& Choi (2012), Bulgarella (2005), Pantouvakis \& Bouranta, (2013), Douglas, Thomas, \& Ingram (1992), Pantouvakis \& Bouranta (2013), Kermani (2013) and Jeon \& Choi (2012), Kermani (2013), Wiley (1991), Pantouvakis \& Bouranta (2013). This can be interpreted with the organizational support to the employees can strongly relate with achieving higher level of CS in Nepalese hospitality sector. It emphasized on managerial implications that CS can be achieved at higher level with creating PJP by improving POS, it supports the findings of Guan, Sun, Hou, Zhao, \& Luan, (2014) that signifies that POS influenced job performance indirectly.

Thus, it may be concluded that the present study provides evidence that CS is correlated with PJP and POS, with mediating effects of POS towards the effect of PJP on CS. POS increase performance of standard job activities and actions favorable to the organization that go beyond assigned responsibilities (Rhoades and Eisenberger 2002). Therefore, hospitality industry in Nepal, should pledge a proper inventiveness in the direction of creating an organizational employee supportive environment to increase the job performance. So that, the ultimate goal of customer satisfaction can be achieved. This will lead the organization towards its achievement of goals. Finally, if the business wants to satisfy the needs of its customers, it must first support its employees. 


\section{Reference}

Ahmad, Z., \& Yekta, Z. (2010). Relationship between perceived organizational support, leadership behavior, and job satisfaction: An empirical study in Iran. Intangible Capital, 6(2), 162-184.

Argyris, C. (1964). Integrating the individual and the organization. New York: Wiley.

Armeli, S., Eisenberger, R., Fasolo, P., \& Lynch, P. (1998). Perceived Organizational Support and Police Performance: The Moderating Influence of Socioemotional Needs . Jounal of Applied Psychology, 83(2), 288-297.

Bagozzi, R.P. and Yi, Y. (1988). On the evaluation of structural equation models. Journal of the Academy of Marketing Science. 16 (1). 74-94.

Biswakarma, G. (2015, Dec). On the Dimensionality of Measuring Tourist Satisfaction Towards Homestay. International Journal of Hospitality \& Tourism Systems., 8(2), 51-63.

Bitne, M. (1992). Servicescapes: the impact of physical surroundings on customer and employees. Journal of Marketing, 56(21), 57-71.

Bitner, M. (1992). Servicescapes: the impact of physical surroundings on customer and employees. Journal of Marketing, 56(21), 57-71.

Bitner, M., \& Hubbert, A. (1994). Encounter satisfaction versus overall satisfaction versus service quality: the consumer's voice. In R. Rustand , \& R. Oliver, Service Quality: New Directions in Theory and Practice. Thousand Oaks, CA: Sage Publications.

Bollen, K.A. (1989). Structural Equations with Latent Variables. John Wiley \& Sons.

Bowra, Z. A., Sharif, B. \&Niazi, M. K. 2011. Impact of human resource practices on employee perceived performance in banking sector of Pakistan. African Journal of Business Management. 6(1). 323-332.

Browne, M.W. \& Cudeck, R. (1993). Alternative ways of assessing model fit. In Bollen, K.A. \& Long, J.S. [Eds.] Testing structural equation models. Newbury Park, CA: Sage, 136-162.

Bryman. A., (2004). Integrating quantitative and qualitative research: how is it done? Qualitative Research. 6: 97.

Bulgarella, C. (2005, Feb). Employee Satisfaction \& Customer Satisfaction: Is There a Relationship? Guidestar Research, 1-6. 
Burke, R., \& GREENGLASS, E. (2001). Hospital restructuring and nursing staff wellbeing: the role of perceived hospital and union support. Anxiety, Stress and Coping: An International Journal, 14, 93-115.

Davar, S., \& Bala, R. (2012, Oct). Relationship between Job Satisfaction \& Job Performance: a Meta-analysis. The Indian Journal of Industrial Relations, 48(2), 290-305.

Douglas, K., Thomas, H., \& Ingram, N. (1992). Service Provider Job Satisfaction and Customer. Journal of Services Marketing, 6(2), 68 - 78.

Duke, A.B., Goodman, J.M., Treadway, D.C. and Breland, J.W. (2009). Perceived organizational support as a moderator of emotional labor/outcomes relationships. Journal of Applied Social Psychology. 39 (5) 1013-1034.

Duncan, E., \& Elliott, G. (2004). Efficiency, customer service and financial performance among Australian financial institutions. The International Journal of Bank Marketing, 22(5), 319-342.

Eisenberger, R., Armeli, S., Rexwinkel, B., Lynch, P.D. and Rhoades, L. (2001). Reciprocation of perceived organizational support. Journal of Applied Psychology. 86 (1) 42-51.

Eisenberger, R., Huntington, R., \& Hutchison, S. (1986). Perceived organizational support. Journal of Applied Psychology, 71, 500-507.

Eisenberger, R., Huntington, R., Hutchinson, S. and Sowa, D. (1986). Perceived organizational support. Journal of Applied Psychology. 71 (3) 500-507.

Gross, E., \& Etzioni, A. (n.d.). Organizations in society. Englewood Cliffs, NJ: Prentice-Hall.

Guan, X., Sun, T., Hou, Y., Zhao, L., \& Luan, Y.-Z. (2014). The relationship between job performance and perceived organizational support in faculty members at Chinese universities: a questionnaire survey. BMC Medical Education, 14(50).

Gursoy, D., McCleary, K., \& Lepsito, L. (2003). Segmenting dissatisfied restaurant customers based on their complaining response styles. Journal of Food Service Business Research, 6(1), 25-44.

Gursoy, D., McCleary, K., \& Lepsito, L. (2007). Propensity to complain: affects of personality and behavioral factors. Journal of Hospitality \& Tourism Research, 31(3), 358-386. 
Hair, J. F., Hult, G. T. M., Ringle, C. M., and Sarstedt, M. (2014). A Primer on Partial Least Squares Structural Equation Modeling (PLS-SEM). Thousand Oaks, CA: Sage.

Hair, J. F., Ringle, C. M., and Sarstedt, M. (2011). "PLS-SEM: Indeed a Silver Bullet." Journal of Marketing Theory and Practice 19 (2): 139-151.

Hair, J., Black, W., Babin, B., and Anderson, R. (2010). Multivariate data analysis. 7th ed. NJ: Prentice-Hall.

Hakkak, M., Gashti, M. H., \& Nawaser, K. (2014). The Relationship between Perceived Organizational Support \& Job Satisfaction with Organizational Commitment. Entrepreneurship and Innovation Management Journal, 2(3), 194-202.

Hanan , A.-A. (2009). Factors affecting performance of hospital nurses in Riyadh Region, Saudi Arabia. International Journal of Health Care Quality Assurance, 22(1), 40 - 54.

Hartline, M.D. and Ferrell, O.C. (1996). The management of customer-contact service employees: an empirical investigation. Journal of Marketing. 60. 5270 .

Hassan, S., Hassan, M., \& Shoaib, M. (2014). Measuring the Impact of Perceived Organization Support, Psychological Empowerment and Rewards on Employees' Satisfaction: Testing the Mediating Impact of Employee Engagement. World Applied Sciences Journal, 30(5), 652-660.

Heskett, J.L., Jones, T.O., Loveman, G.W., Sasser, W.E. Jr and Schlesinger, L.A. (2008). Putting the service-profit chain to work. Harvard Business Review. July-August. 118-29.

Hoffman K. D. and Ingram T. N., (1992). Service Provider Job Satisfaction and Customer. Journal of Services Marketing, 6(2) 68 - 78.

Hu, L., \& Bentler, P. M. (1999). Cutoff criteria for fit indexes in covariance structure analysis: Conventional criteria versus new alternatives. Structural Equation Modeling, 6, 1-55.

Hu, L.-T., \& Bentler, P. (1995). Evaluating model fit. In R. H. Hoyle (Ed.), Structural Equation Modeling. Concepts, Issues, and Applications. London: Sage. 
Hur, Won-Moo., Han, Su-Jin., Yoo, Jeong-Ju., Moon, Tae-Won (2015). The moderating role of perceived organizational support on the relationship between emotional labor and job-related outcomes. Management Decision, 53

(3) $605-624$.

Jeon , H., \& Choi, B. (2012). The relationship between employee satisfaction and customer satisfaction. Journal of Services Marketing, 26(5), 332-341.

Johnson, M. D., \& Gustafsson, A. (2000). Improving Customer Satisfaction, Loyalty and Profit:An Integrated Measurement and Management System.

Judge , T., Bono , J., Thoresen , C., \& Patton, G. (2001). The Job Satisfaction-Job Performance Relationship: A Qualitative and Quantitative Review. Psychological Bulletin, 127, 376-407.

Kahya, E. (2008). The effects of job performance on effectiveness. International Journal of Industrial Ergonomics, 39(1), 96 -104.

Karatepe, M. (2011). Perceived organizational support, career satisfaction, and performance outcomes: A study of hotel employees in Cameroon.

International Journal of Contemporary Hospitality Management. 24 (5) 735 752 .

Keaveney, S., \& Nelson, J. (1993). Coping with organizational Role Stress: Intrinsic Motivational Orientation, Perceived Role Benefits, and Psychological Withdrawal. Journal of the Academy of Marketing Science, 21, 113-24.

Kermani, Z. (2013). A Study of the Linking Between Job Satisfaction and Customer Satisfaction: A Case Study of Iran Insurance; Kerman, Iran. Journal of Marketing Development and Competitiveness, 7(4), 104-109.

Lilford, N. (n.d.). Determining the relationship between job satisfaction and customer service levels at a small retailer in South Africa. International Retail and Marketing Review, 74-79.

Locke, L. (1969). What is Job Satisfaction? rganizational Behavior and Human Performance, 4, 309-336.

Mowday, R. (1998). Reflection on the study and the relevance of organizational commitment. Human Resource Management Review, 8(4), 387-401.

Mulaik, S. A., and James, L. R. (1995). Objectivity and reasoning in science and structural equation modeling. In: R. H. Hoyle, ed. Structural Equation Modeling: Concepts, issue and applications. CA: Sage Publications. pp. 118137. 
Nabirye, R., Brown, K., Pryor, E., \& Marles, E. (2011). Occupational stress, job satisfaction and job performance among hospital nurses in Kampala, Uganda. Journal of Nursing Management, 19(6), 760-768.

Nejatian, H., Piaralal, S. K., Sentosa, I., and Bohari, A. M. (2011). The Influence of Customer Knowledge on CRM Performance of Malaysian ICT Companies: A Structural Equation Modeling Approach. International Journal of Business and Management, 6 (7), p.181. [Online] www.ccsenet.org/ijbm, doi:10.5539/ijbm.v6n7p181 Canadian Center of Science and Education (CCSE), [Accessed 22 Aug 2015].

Nunnally, J. (1978). Psychometric theory 2nd edition. McGraw-Hill: New York.

Olsen, L. L., Witell, L., \& Gustafsson, A. (2014). Turning customer satisfaction measurements into action. Journal of Service Management, 25(4), 556 - 571.

Pantouvakis , A., \& Bouranta, N. (2013). The interrelationship between service features, job satisfaction and customer satisfaction: Evidence from the transport sector. The TQM Journal, 25(2), 186-201.

Peterson, R. A., \& Wilson, W. R. (1992). Measuring customer satisfaction: fact and artefact. Journal of the Academy of Marketing Science, 20(1), 61-72.

Platisa, C., Reklitisb, P., \& Zimerasc, S. (2015). Relation between job satisfaction and job performance in healthcare services. Procedia - Social and Behavioral Sciences, $175,480-487$.

Pugno, M., \& Depedri, S. (2009). Job performance and job satisfaction: an integrated survey. Discussion Paper No. 4, Universita Degli Studi Di Trent, Dipartimento di Economia.

Ravindran , C. (2007). Study of Factors Influencing the Work Output of Human Resource in Revised National Tuberculosis Control Program (RNTCP). Pulmon, 9(3), 88-96.

Rhoades, L. and Eisenberger, R. (2002). Perceived organizational support: a review of the literature. Journal of Applied Psychology. 87 (4) 698-714.

Rhoades, L., Eisenberger, R., \& Armeli, S. (2001). Affective commitment to the organization: The contribution of perceived organizational support. Journal of Applied Psychology, 86, 825-836.

Ryan, A.M., Schmit, M.J. and Johnson, R. (1996). Attitudes and effectiveness: examining relations at an organizational level. Personnel Psychology. 49, 853-882. 
Schmit, M.J. and Allscheid, S.P. (1995). Employee attitudes and customer satisfaction: making theoretical and empirical Connections. Personnel Psychology, 48 (3) 521-537.

Settoon, R., Bennett, N., \& Liden, R. (1996). Social exchange in organizations: perceived organizational support, leader-member exchange, and employee reciprocity. Journal of Applied Psychology, 81, 219-227.

Singh, A., \& Singh, A. (2010). Role of Stress and organization in shape of higher engagement and satisfaction. The IUP Journal of Organizational Behavior, IX(4), 7-25.

Spiro, R., \& Weitz, B. (1990). Adaptive selling: conceptualization, measurement, and nomological validity. Journal of Marketing Research, 27(1), 61-69.

Steiger, J.H. (1989). EZPATH: A supplementary module for SYSTAT and SYGRAPH. Evanston, IL: SYSTAT.

Sternberg, L. (1992). Empowerment: Trust vs. control. Cornell Hotel \& Restaurant Administration Quarterly, 33(1), 68.

Susskind, A.M., Borchgrevink, C.P., Kacmar, K.M. and Brymer, R.A. (2000). Customer service employees' behavioral intentions and attitudes: an examination of construct validity and a path model. International Journal of Hospitality Management. 19 (1) 53-77.

Vroom, V. (1964). Work and Motivation. New York: Wiley.

Wayne, S., Shore, 1., \& Liden, R. (1997). Perceived organizational support and leader-member exchange: a social exchange perspective. Academy of Management Journal, 40, 82-111.

Wickramasinghe , D., \& Wickramasinghe, V. (2012). Effects of perceived organisational support on participation in decision making, affective commitment and job satisfaction in lean production in Sri Lanka. Journal of Manufacturing Technology Management, 23(2), 157 - 177.

Wiley, J. (1991). Customer satisfaction: a supportive work environment its financial cost. Human Resource Panning, 44(2), 117-127.

Yavas, U., Karatepe, M. O and Babakus, E. (2010). Relative efficacy of organizational support and personality traits in predicting service recovery and job performances: a study of frontline employees in Turkey. Tourism Review. 65 (3) 70-83. 


\section{Annexure 01}

\section{Rotated Component Matrix}

\begin{tabular}{|c|c|c|c|c|}
\hline items & Opinion Statements & \multicolumn{3}{|c|}{ Component } \\
\hline & & CS & POS & $\mathbf{P J P}$ \\
\hline POS1 & My organization really cares about my well-being & & .851 & \\
\hline POS2 & My organization strongly considers my goals and values & & .781 & \\
\hline POS3 & $\begin{array}{l}\text { My organization shows little concern for me (do not } \\
\text { concern) }\end{array}$ & & .810 & \\
\hline POS4 & My organization cares about my opinions & & .518 & \\
\hline POS5 & $\begin{array}{l}\text { My organization is willing to help me if I need a special } \\
\text { favor }\end{array}$ & & .873 & \\
\hline POS6 & $\begin{array}{l}\text { Help is available from my organization when I have a } \\
\text { problem }\end{array}$ & & 674 & \\
\hline POS7 & $\begin{array}{l}\text { My organization would forgive an honest mistake on my } \\
\text { part }\end{array}$ & & .896 & \\
\hline POS8 & $\begin{array}{l}\text { If given the opportunity, my organization would take } \\
\text { advantage of me. }\end{array}$ & & .857 & \\
\hline PJP1 & $\begin{array}{l}\text { My performance is better than that of my colleagues with } \\
\text { similar qualifications }\end{array}$ & & & .677 \\
\hline PJP2 & $\begin{array}{l}\text { I am satisfied with my performance because it is mostly } \\
\text { good }\end{array}$ & & & .597 \\
\hline PJP3 & $\begin{array}{l}\text { My performance is better than that of employees with } \\
\text { similar qualifications in other organizations }\end{array}$ & & & .821 \\
\hline CS1 & I intend to continue using this hotel & .861 & & \\
\hline $\mathrm{CS} 2$ & I would recommend this hotel to other people & .886 & & \\
\hline CS3 & I would like to stay in this hotel next time & .909 & & \\
\hline CS4 & I would like repurchase many services in this hotel & .777 & & \\
\hline CS5 & I would encourage friends and relatives to visit this hotel & .922 & & \\
\hline CS6 & I consider the performance in this hotel strong & .863 & & \\
\hline CS7 & $\begin{array}{l}\text { I would consider this hotel as my first choice when I need } \\
\text { a hotel service }\end{array}$ & .884 & & \\
\hline CS8 & I am overall satisfied with the service quality of the Hotel. & .899 & & \\
\hline
\end{tabular}

